\title{
Estimasi Potensi Penyerapan Karbondioksida Atmosfer di Daerah Tangkapan Air Sistem Sungai Bawah Tanah Goa Pindul sebagai Upaya untuk Menekan Pemanasan Global
}

\author{
Rizka Ratna Sayekti, Slamet Suprayogi dan Ahmad Cahyadi \\ Departemen Geografi Lingkungan, Fakultas Geografi, Universitas Gadjah Mada \\ Yogyakarta
}

\section{Intisari}

Perubahan iklim dan pemanasan global telah menjadi isu dunia. Berbagai penelitian telah dilakukan untuk mencegah semakin besarnya perubahan iklim global, di antaranya adalah dengan melihat penyerapan alamiah dari gas rumah kaca khususnya karbondioksida oleh proses alamiah. Penyerapan karbondioksida atmosfer oleh proses karstifikasi dipercaya memberikan dampak yang besar dalam mengurangi konsentrasi karbondioksida atmosfer. Penelitian ini bertujuan untuk mengetahui peranan dan besaran dari penyerapan karbondioksida atmosfer melalui proses karstifikasi di Daerah Tangkapan Air (DTA) Sistem Goa Pindul di kabupaten Gunungkidul. Hasil penelitian menunjukkan bahwa sebesar 966,79 ton/tahun/luas karbondioksida diserap dalam proses karstifikasi untuk melarutkan 8.056,57 ton batugamping; dan kapasitas penyerapan karbondioksida yang diserap tersebut melebihi emisi karbondioksida yang bertambah 2,3 ton setiap tahunnya di Indonesia.

Kata kunci: Karst, Karstifikasi, Penyerapan Karbondioksida

\section{Pendahuluan}

Karbondioksida $\left(\mathrm{CO}_{2}\right)$ merupakan salah satu emisi yang menyusun gas rumah kaca di samping metana $\left(\mathrm{CH}_{4}\right)$, nitrogen oksida $\left(\mathrm{N}_{2} \mathrm{O}\right)$, dan uap air $\left(\mathrm{H}_{2} \mathrm{O}\right)$. Gas rumah kaca dalam keadaan normal berfungsi menjaga Bumi agar tetap hangat dengan menyerap radiasi panas matahari. Tanpa adanya gas rumah kaca, suhu Bumi akan lebih dingin dibandingkan suhu saat ini. Akan tetapi, sejak revolusi industri pada pertengahan 1880-an, terjadi perubahan kandungan emisi-emisi penyusun gas rumah kaca (Cahyadi 2010). Emisi $\mathrm{CO}_{2}$ meningkat lebih dari dua kali lipat dari 1.400 juta ton/tahun pada dekade terdahulu menjadi 2.900 juta ton/tahun dalam 
dekade sekarang. Tidak dapat dipungkiri bahwa telah terjadi perubahan iklim yang menyebabkan pemanasan global berupa peningkatan suhu gas rumah kaca menjadi $0,5^{\circ} \mathrm{C}$ lebih panas dibandingkan dengan suhu sebelum revolusi industri (Murdiyarso, 2005).

Wilayah karst memiliki fungsi dalam penyerapan karbondioksida $\left(\mathrm{CO}_{2}\right)$ atmosfer yang besar (Cahyadi dkk., 2013a, Cahyadi dkk., 2015). Karbondioksida adalah karbon dalam bentuk gas dan menjadi bagian dalam siklus alami karbon. Karbon dalam bentuk bukan gas disimpan di dalam makhluk hidup dan benda alam yang termasuk di dalamnya adalah batugamping (Suprianto dan Solihat, 2012). Bentang alam karst dibentuk oleh batugamping yang tersebar luas di Indonesia (Cahyadi, 2010). Karst Indonesia yang cukup terkenal di antaranya adalah karst Gunungsewu yang membentang di Pulau Jawa, dari Jawa Tengah, Yogyakarta, hingga Jawa Timur (Darajati dkk., 2016).

Karst adalah bentang alam dengan karakteristik hidrologi khas. Karst disusun oleh batuan mudah larut oleh air dan mempunyai porositas sekunder yang berkembang baik (Ford and Williams, 2007). Wilayah karst saat ini diakui telah berperan dalam menekan terjadinya pemanasan global (global warming) karena dungsinya dalam menyerap karbondioksida atmosfer. Indonesia diperkirakan memiliki wilayah karst seluas 140.000.000 $\mathrm{km}^{2}$. Karst di Indonesia ini mampu menyerap $13.428 \mathrm{Gg} \mathrm{CO}_{2} /$ tahun (Haryono, 2011).

Penyerapan karbondioksida $\left(\mathrm{CO}_{2}\right)$ tidak terlepas dari proses pelarutan batugamping atau biasa disebut dengan proses karstifikasi. Proses karstifikasi dapat terjadi pada wilayah dengan iklim tropis basah dengan curah hujan tinggi dan suhu kondusif serta tutupan vegetasi yang rapat (Blair and Robert, 1986). Meskipun penelitian terbaru menyebutkan bahwa pelarutan dapat terjadi di semua tipe iklim dengan kecepatan yang berbedabeda. Selain itu, kemurnian dan tebal batugamping $\left(\mathrm{CaCO}_{3}\right)$ serta kandungan karbondioksida $\left(\mathrm{CO}_{2}\right)$ terlarut dalam air mempengaruhi tingkat karstifikasi yang terjadi (Haryono dan Adji, 2004). Rata-rata pelarutan batugamping di dunia adalah $87,41 \mathrm{~m}^{3} / \mathrm{km}^{2}$ (Daoxian, 2002). Menurut Cahyadi dan Priadmodjo (2015), setiap proses pelarutan $1.000 \mathrm{~kg}$ batugamping akan diikuti dengan penyerapan karbondioksida dari atmosfer sebesar $120 \mathrm{~kg}$. Proses karstifikasi dalam kaitannya dengan sistem dinamis karst (Karst Dynamic System) memiliki 3 fase, yaitu fase padat, cair, dan gas (Zhongcheng and Daoxian, 1999; Haryono dan Adji, 2004). Konsep sistem dinamis karst dapat dilihat pada Gambar 1. 


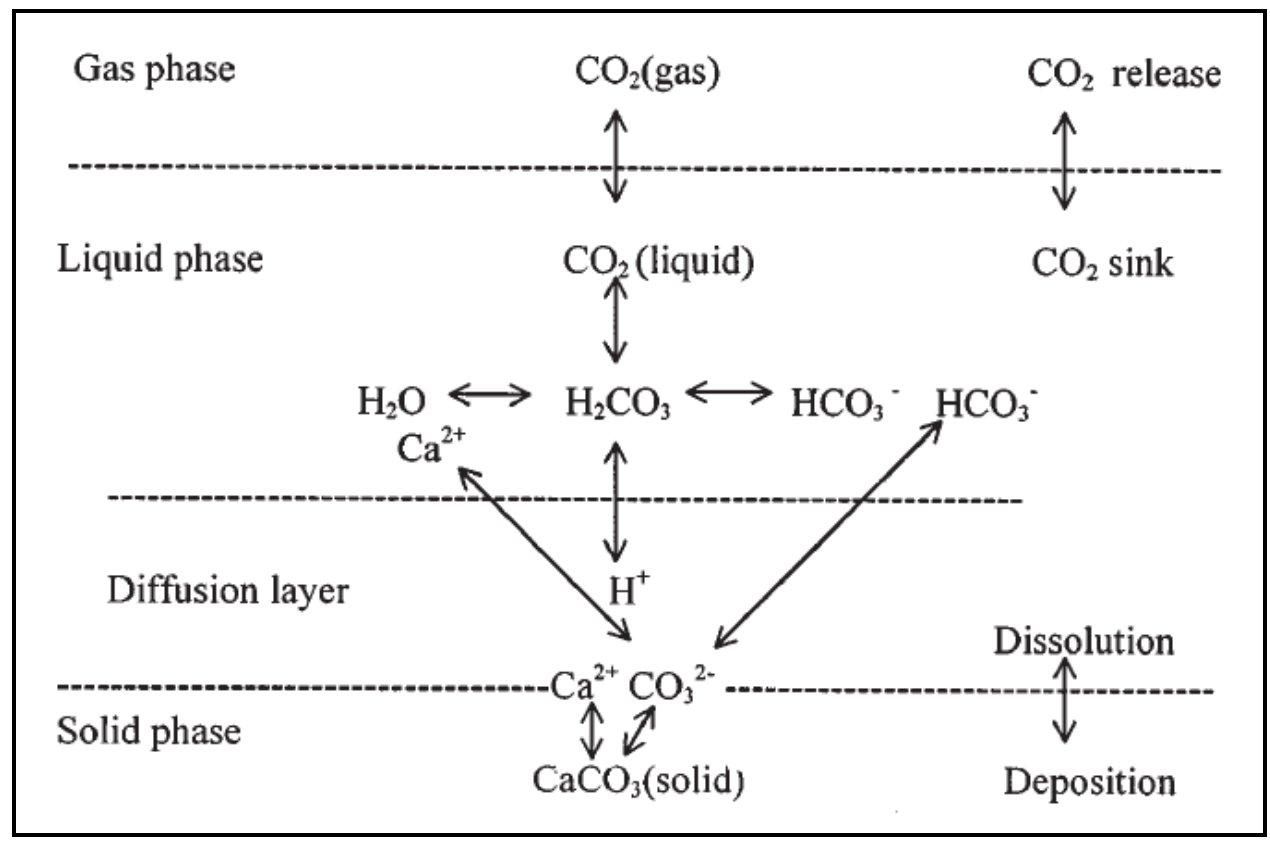

Gambar 1: Model Konsep Sistem Dinamis Karst

(Zhongcheng and Daoxian, 1999)

Secara sederhana, proses karstifikasi dirumuskan dengan persamaan 1. Kawasan karst dicirikan dengan berkembangnya jalur-jalur sungai bawah permukaan dan minimnya sungai permukaan (Adji, 2013; Cahyadi dkk., 2013b). Salah satu sungai di karst Gunungsewu adalah sungai di Goa Pindul. Sungai di Goa Pindul merupakan sungai bawah permukaan yang di beberapa lokasi muncul sebagai sungai permukaan. Sungai ini menjadi bagian dari kesatuan hidrologi dalam daerah tangkapan air yang disebut Daerah Tangkapan Air (DTA) Sistem Goa Pindul.

$$
\mathrm{CaCO}_{3}+\mathrm{CO}_{2}+\mathrm{H}_{2} \mathrm{O} \rightarrow \mathrm{Ca}^{2-}+2 \mathrm{HCO}_{3}^{-} \text {(Blair and Robert, 1986) }
$$

Daerah Tangkapan Air Sistem Goa Pindul terletak di Kecamatan Karangmojo, Gunungkidul. Luas daerah tangkapan air sebesar 15,44 km². Daerah tangkapan air ini mendapatkan masukan (input) air dari hujan dan mataair, di antara lain Mataair Mbeji, Mudal, Jebul, dan Ngancar. Sebagai wilayah karst, daerah tangkapan air ini ikut berperan dalam penyerapan karbondioksida di atmosfer. Oleh karena itu, dilakukan penelitian untuk menganalisis volume karbondioksida atmosfer yang dapat diserap oleh DTA Sistem Goa Pindul. Tujuan dari penelitian ini adalah sebagai berikut: 
1. Menjelaskan terjadinya proses karstifikasi di DTA Sistem Goa Pindul;

2. Mengetahui kapasitas penyerapan karbondioksida di DTA Sistem Goa Pindul untuk melarutkan batugamping dalam proses karstifikasi; dan

3. Menganalisis kontribusi DTA Sistem Goa Pindul dalam menekan pemanasan global (global warming).

\section{Metode Penelitian}

Perhitungan karbondioksida yang dapat diserap oleh DTA Sistem Goa Pindul dapat dihitung dengan rumus Daoxian (2002). Menurut Daoxian, volume karbondioksida yang terserap merupakan hasil perkalian discharge dengan konsentrasi $\mathrm{HCO}_{3}^{-}$dan nilai koefisiennya. Besarnya discharge sendiri diketahui dari pengolahan data sekunder. Kemudian konsentrasi $\mathrm{HCO}_{3}{ }^{-}$didapatkan dari titrasi terhadap sampel mataair dengan menggunakan Alkalinity Test Kit. Mataair yang diuji meliputi Mataair Mbeji, Mudal, Jebul, dan Ngancar. Rumus untuk menghitung kapasitas penyerapan karbondioksida adalah ditunjukkan oleh persamaan 2 .

$$
\boldsymbol{C}=Q \times\left[\frac{\mathrm{HCO}_{3}}{2} \times \frac{12}{61}\right](\text { Daoxian, 2002) }
$$

Keterangan:

$\mathrm{C} \quad=$ Kapasitas penyerapan karbondioksida (g/tahun)

$\mathrm{Q}=$ Discharge (m3/tahun/luas)

$\mathrm{HCO}_{3}=$ Konsentrasi $\mathrm{HCO}_{3}^{-}(\mathrm{mg} / \mathrm{l})$

Discharge adalah besarnya runoff yang terjadi dikali dengan luas wilayah kajian. Nilai runoff dihasilkan dari besar presipitasi dikurangi oleh evapotranspirasi potensial. Rumus dalam menghitung discharge ditunjukkan pada persamaan 3 .

$$
Q=(P-E a) \times A
$$

Keterangan:

$\mathrm{Q}=$ Discharge $\left(\mathrm{m}^{3} /\right.$ tahun/luas)

$\mathrm{P} \quad=$ Hujan (m/tahun)

$\mathrm{Ea} \quad=$ Evapotranspirasi potensial (m/tahun)

A $=$ Luas wilayah kajian $\left(\mathrm{m}^{2}\right)$ 
Presipitasi atau hujan adalah titik-titik air yang jatuh dari awan ke permukaan Bumi. Presipitasi didapatkan dari perhitungan hujan rata-rata dengan asumsi hujan yang terjadi distribusinya dianggap merata dalam DTA Sistem Goa Pindul. Perhitungan hujan rata-rata menggunakan metode isohyet. Isohyet adalah garis kontur yang menghubungkan tempat-tempat yang mempunyai curah hujan yang sama (Hadisusanto, 2010). Perhitungan hujan rata-rata dapat dirumuskan pada persamaan 4 .

$\boldsymbol{P}=\frac{\left(\frac{X 1+X 2}{2}\right) \times A 1+\left(\frac{X 2+X 3}{2}\right) \times A 2+\cdots+\left(\frac{X n 1+X n 2}{2}\right) \times A n}{A 1+A 2+\cdots+A n}$ (Hadisusanto, 2010)

Keterangan:

$\mathrm{P} \quad=$ hujan rata-rata $(\mathrm{mm})$

$\mathrm{X} 1, \mathrm{X} 2 . . \mathrm{Xn}=$ jumlah hujan berdasarkan garis kontur $(\mathrm{mm})$

$\mathrm{A} 1, \mathrm{~A} 2 . . \mathrm{An}=$ luas sub area 2 garis kontur $\left(\mathrm{km}^{2}\right)$

Evapotranspirasi merupakan peristiwa kehilangan air dari jaringan tanaman dan permukaan tanah yang dipakai sebagai tempat tumbuh tanaman. Evapotranspirasi potensial oleh Penman diartikan sebagai proses evapotranspirasi yang terjadi pada tanaman hijau, mempunyai ketinggian pendek dan seragam serta menutup permukaan tanah secara sempurna dan tidak pernah mengalami kekurangan air selama pertumbuhannya (Hadisusanto, 2010). Perhitungan evapotranspirasi menggunakan metode Turc-Lungbein dengan persamaan 5 . Nilai evaporasi aktual didapatkan dari persamaan 6 .

$$
\boldsymbol{E} \boldsymbol{\alpha}=\frac{\boldsymbol{P}}{\left[0,9+\left(\frac{P^{2}}{E 0^{2}}\right)^{\frac{1}{2}}\right.} \quad \text { (Sosrodarsono dan Takeda, 2006) ..... (5) }
$$

Keterangan:

$\mathrm{Ea}=$ Evapotranspirasi potensial (mm/tahun)

$\mathrm{P} \quad=$ Curah hujan tahunan (mm/tahun)

Eo = Evaporasi aktual ( $\mathrm{mm} / \mathrm{tahun})$

$\mathrm{T} \quad=$ Rerata temperatur tahunan $\left({ }^{\circ} \mathrm{C}\right)$

$$
\boldsymbol{E} \boldsymbol{o}=\mathbf{3 2 5}+\mathbf{2 1 T}+\mathbf{0 , 9} \boldsymbol{T}^{\mathbf{2}} \quad \text { (Sosrodarsono dan Takeda, 2006) } \ldots .(6)
$$

Wilayah kajian terdapat stasiun pengukuran hujan, yaitu Stasiun Gedangan, yang mana stasiun ini tidak memiliki data suhu sehingga 
diperlukan perhitungan suhu untuk analisis. Perhitungan suhu dilakukan dengan menggunakan metode Mock. Suhu yang digunakan dalam kajian ini adalah data suhu yang disesuaikan dengan median elevasi dari DTA Sistem Pindul. Rumus Mock mengharuskan memasukkan data elevasi tempat stasiun koreksi dan terkorelasi, maka ketinggian yang digunakan adalah ketinggian median elevasi dari DTA Sistem Pindul. Rumus perhitungan suhu metode Mock ditunjukkan pada persamaan 7.

$$
T=0,006 \times\left(Z_{1}-Z_{2}\right)^{\circ} \mathrm{C} \quad(\text { Triadmodjo, 2010) }
$$

$$
\begin{aligned}
& \text { Keterangan: } \\
& \begin{array}{ll}
\mathrm{T} & =\text { Beda temperatur udara antara } \mathrm{Z}_{1} \text { dan } \mathrm{Z}_{2}\left({ }^{\circ} \mathrm{C}\right) \\
\mathrm{Z}_{1} & =\text { Elevasi stasiun koreksi (Stasiun Wanogomo) } \\
\mathrm{Z}_{2} & =\text { Elevasi stasiu terkorelasi (Stasiun Gedangan) }
\end{array}
\end{aligned}
$$

\section{Hasil dan Pembahasan}

Proses karstifikasi diawali dengan pelarutan batuan gamping $\left(\mathrm{CaCO}_{3}\right)$ oleh air $\left(\mathrm{H}_{2} \mathrm{O}\right)$ dan karbondioksida $\left(\mathrm{CO}_{2}\right)$, sehingga menghasilkan $\mathrm{Ca}^{2}+$ dan $\mathrm{HCO}_{3}-$ dalam bentuk cair (liquid). Karena proses karstifikasi, setiap badan air di wilayah karst, termasuk mataair, akan mengandung $\mathrm{Ca}^{2+}$ dan $\mathrm{HCO}_{3}{ }^{-}$ dalam konsentrasi yang tinggi. Besar konsentrasi $\mathrm{Ca}^{2+}$ dan $\mathrm{HCO}_{3}{ }^{-}$dalam mataair dapat mempresentasikan karbondioksida yang dapat diserap oleh proses karstifikasi. Oleh karena itu, dalam analisis penyerapan karbondioksida, dilakukan pengukuran konsentrasi $\mathrm{Ca}^{2+}$ dan $\mathrm{HCO}_{3}{ }^{-}$di setiap mataair pada DTA Sistem Goa Pindul. Konsentrasi $\mathrm{Ca}^{2+}$ dan $\mathrm{HCO}_{3}{ }^{-}$setiap mataair dapat dilihat pada Tabel 1.

Tabel 1. Konsentrasi $\mathrm{Ca}^{2+}$ dan $\mathrm{HCO}_{3}{ }^{-}$pada Setiap Mataair di DTA Sistem Goa Pindul

\begin{tabular}{|l|l|r|r|r|r|}
\hline Titik & \multicolumn{1}{|c|}{ Nama } & $\begin{array}{c}\text { Titrasi Ca }^{2+} \\
(\mathbf{m g} / \mathbf{l})\end{array}$ & $\begin{array}{c}\text { Titrasi } \\
\mathrm{HCO}^{-} \\
(\mathbf{m g} / \mathbf{l})\end{array}$ & $\begin{array}{c}\text { DHL } \\
(\mathbf{m i c r o S})\end{array}$ & $\begin{array}{c}\text { Suhu } \\
\left({ }^{\circ} \mathbf{C}\right)\end{array}$ \\
\hline 1 & Mataair Mbeji & 124,00 & 518,29 & 600,00 & 28,00 \\
\hline 2 & Mataair Mudal & 124,00 & 414,63 & 629,00 & 28,40 \\
\hline 3 & Mataair Jebul & 124,00 & 414,63 & 637,00 & 28,80 \\
\hline 4 & Mataair Ngancar & 122,00 & 396,34 & 585,00 & 28,70 \\
\hline \multicolumn{2}{|l|}{ Rata-rata } & 123,50 & 435,98 & 612,75 & 28,48 \\
\hline
\end{tabular}

Sumber: Data Lapangan (2016) 
Setiap mataair yang diuji memiliki konsentrasi $\mathrm{Ca}^{2+}$ dan $\mathrm{HCO}_{3}^{-}$yang bervariasi. Mataair Mbeji memiliki konsentrasi $\mathrm{HCO}_{3}^{-}$paling tinggi, yaitu $518,29 \mathrm{mg} / \mathrm{l}$, dan mataair Ngancar memiliki konsentrasi $\mathrm{HCO}_{3}{ }^{-}$terkecil, yaitu 396,34 mg/l. Mataair Mbeji, Mudal, dan Jebul memiliki nilai konsentrasi $\mathrm{Ca}^{2+}$ yang sama, yaitu $124 \mathrm{mg} / \mathrm{l}$, sedangkan Mataair Ngancar memiliki konsentrasi $\mathrm{Ca}^{2+}$ sebesar $122 \mathrm{mg} / \mathrm{l}$. Semakin besar konsentrasi $\mathrm{Ca}^{2+}$ dan $\mathrm{HCO}_{3}{ }^{-}$, maka semakin intensif proses karstifikasi yang terjadi.

Konsentrasi $\mathrm{Ca}^{2+}$ dan $\mathrm{HCO}_{3}{ }^{-}$di DTA Sistem Goa Pindul menunjukkan tingginya intensitas proses karstifikasi. Karena proses karstifikasi yang intensif, DTA Sistem Goa Pindul dapat menyerap karbondioksida dalam jumlah yang besar. Proses karstifikasi tidak terlepas dari faktor-faktor pendorong. Adapun faktor yang berpengaruh pada proses karstifikasi di antaranya adalah tutupan vegetasi yang rapat, perilaku manusia terhadap lingkungan, curah hujan yang tinggi, dan suhu (Haryono dan Adji, 2004).

Daerah Tanngkapan Air Sistem Goa Pindul memiliki tutupan vegetasi yang rapat. Vegetasi yang rapat sangat baik dalam proses karstifikasi. Vegetasi menghasilkan humus pada akarnya, sehingga menyebabkan $\mathrm{pH}$ rendah atau asam di sekitarnya. Ketika air limpasan permukaan mengalami infiltrasi secara diffuse, maka air tersebut tercampur dengan humus yang dihasilkan oleh vegetasi. Hal ini menyebabkan air yang meresap melalui lapisan tanah memiliki $\mathrm{pH}$ asam yang mempermudah untuk melarutkan batugamping. Selain menghasilkan humus, akar vegetasi dalam tanah menciptakan rekahan atau diaklas. Munculnya diaklas-diaklas pada batugamping akan semakin mempermudah terinfiltrasinya air secara conduit, sehingga pelarutan batugamping menjadi semakin intensif.

Pengaruh kerapatan tutupan vegetasi terhadap proses karstifikasi dapat dilihat pada konsentrasi $\mathrm{HCO}_{3}{ }^{-}$di setiap mataair. Mataair Mbeji memiliki tutupan vegetasi yang paling rapat, sehingga didapatkan konsentrasi $\mathrm{HCO}_{3}{ }^{-}$ tertinggi dibandingkan mataair lainnya. Kerapatan vegetasi pada Mataair Mudal dan Mataair Jebul tidak serapat tutupan vegetasi pada Mataair Mbeji. Wilayah sekitar kedua mataair ini cenderung terbuka dengan tutupan lahan antara lain lahan kosong, bangunan, dan sebagian vegetasi. Karakteristik wilayah yang sama menyebabkan Mataair Mudal dan Mataair Jebul memiliki konsentrasi $\mathrm{HCO}_{3}^{-}$yang sama. Akan tetapi, kondisi vegetasi yang rapat pada Mataair Ngancar tidak menyebabkan pengaruh yang besar terhadap proses karstifikasi. Konsentrasi $\mathrm{HCO}_{3}^{-}$Mataair Ngancar paling sedikit di antara mataair lainnya. Hal ini berarti bahwa terdapat faktor lainnya yang mempengaruhi proses karstifikasi di wilayah sekitar Mataair Ngancar.

Perilaku manusia ikut serta dalam menentukan kelestarian ekosistem karst. Permasalahan yang kerap timbul saat ini adalah perilaku manusia 
telah menyebabkan kerusakan lingkungan sehingga alam kehilangan fungsi hidupnya. Perilaku manusia yang menyebabkan kerusakan karst antara lain eksploitasi hutan, penambangan batugamping, dan pembangunan yang kian intensif. Kerusakan karst akan menyebabkan proses karstifikasi terganggu. Akibatnya, karst akan kehilangan fungsinya sebagai penyerap karbondioksida di atmosfer.

Daerah Tangkapan Air Sistem Goa Pindul menjadi salah satu kawasan karst yang telah mendapatkan ganggoan dari manusia. Perkembangan pariwisata yang sangat pesat di Goa Pindul telah mendorong dibangunnya fasilitas penunjang, seperti jalan dan rumah makan. Dibangunnya fasilitas penunjang diikuti dengan pembukaan lahan yang dapat mengurangi kuantitas vegetasi dan batugamping. Kegiatan ini dapat menyebabkan proses karstifikasi terganggu. Hal ini nampak pada proses karstifikiasi yang terjadi di wilayah sekitar Mataair Ngancar. Mataair Ngancar muncul di wilayah dengan kerapatan vegetasi yang rapat. Namun, konsentrasi $\mathrm{HCO}_{3}{ }^{-}$ di Mataair Ngancar lebih sedikit dibandingkan mataair lainnya. Hal ini disebabkan karena tidak jauh dari Mataair Ngancar, terdapat pembukaan lahan untuk dibangun jalan dan rumah makan. Kemudian terjadi pengerukan batugamping dalam rangka membuka tempat wisata baru setelah ditemukannya goa oleh masyarakat. Pengerukan batugamping dan goa dapat dilihat pada Gambar 2. Karena pengaruh manusia tersebut, proses karstifikasi di wilayah karst sekitar Mataair Ngancar tidak terlalu intensif seperti wilayah lainnya.

Proses karstifikasi membutuhkan jumlah air $\left(\mathrm{H}_{2} \mathrm{O}\right)$ yang cukup banyak untuk melarutkan batugamping $\left(\mathrm{CaCO}_{3}\right)$. Air tersebut bersumber dari air hujan yang meresap ke dalam tanah. Menurut Haryono dan Adji (2004), curah hujan minimal untuk melarutkan batugamping adalah $250 \mathrm{~mm} / \mathrm{tahun}$. Sementara itu, perhitungan hujan wilayah menghasilkan nilai sebesar 1.780 $\mathrm{mm} /$ tahun. Hal ini berarti bahwa hujan yang jatuh di DTA Sistem Goa Pindul tergolong tinggi dan cukup untuk melarutkan batugamping.

Suhu yang tinggi di DTA Sistem Goa Pindul sangat sesuai untuk melarutkan batugamping. Perhitungan suhu di DTA Sistem Goa Pindul menghasilkan nilai sebesar $23,71^{\circ} \mathrm{C}$. Diketahuinya suhu dapat mempermudah analisis evaporasi aktual dan evapotranspirasi potensial. Bersama dengan hujan, nilai evapotranspirasi potensial digunakan untuk mencari besarnya discharge untuk proses pelarutan. Dengan demikian, kapasitas penyerapan karbondioksida DTA Sistem Goa Pindul dapat diketahui. Rincian nilai analisis penyerapan karbondioksida dapat dilihat pada Tabel 2. 


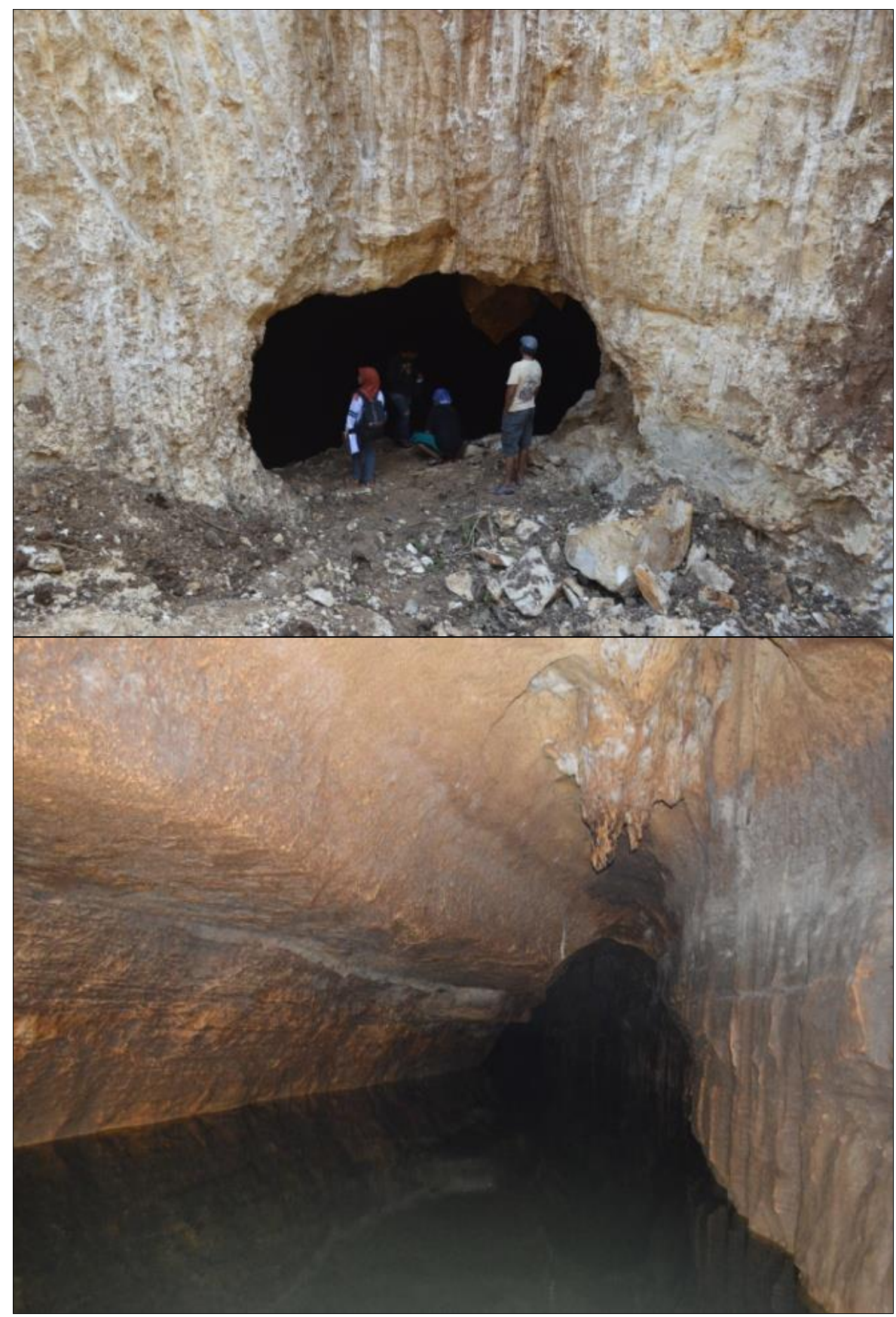

Gambar 2. Pembukaan Wisata di Goa yang Ditemukan Masyarakat dengan Cara Pengerukan Batugamping (Foto Oleh Galih Dwi Jayanto, 2016) 
Tabel 2. Penyerapan Karbondioksida DTA Sistem Goa Pindul

\begin{tabular}{|l|l|r|}
\hline No & Unsur & Nilai \\
\hline 1 & Curah Hujan Wilayah (mm/tahun) & $1.780,38$ \\
\hline 2 & Suhu Udara (C) & 23,71 \\
\hline 3 & Evaporasi Aktual (mm/tahun) & 325,00 \\
\hline 4 & Evapotranspirasi Potensial (mm/tahun) & 320,23 \\
\hline 5 & Runoff $(\mathrm{dm})$ & 14,60 \\
\hline 6 & $\mathrm{HCO}_{3}(\mathrm{mg} / \mathrm{lt})$ & 435,98 \\
\hline 7 & Luas $(\mathrm{km})$ & 15,44 \\
\hline 8 & Discharge (m3/tahun/luas) & $22.544 .891,00$ \\
\hline 9 & Karbondioksida yang terserap (ton/tahun/luas) & 966,79 \\
\hline 10 & Volume penyerapan (m3/tahun/luas) & 193,26 \\
\hline
\end{tabular}

Sumber: Pengolahan Data (2016)

Daerah Tangkapan Air Sistem Goa Pindul memiliki potensi penyerapan karbondiosida yang sangat besar. Kapasitas penyerapan karbondioksida di DTA Sistem Goa Pindul sebesar 966,79 ton/tahun/luas. Kapasitas penyerapan karbondioksida tersebut diikuti dengan pelarutan batugamping sebesar 8.056,57 ton atau setara dengan volume 193,26 $\mathrm{m}^{3} / \mathrm{km}$. Menurut Daoxin (2002), total penyerapan karbondioksida di dunia adalah $6,08 \times 10^{8}$ ton/tahun. Dengan demikian, DTA Sistem Goa Pindul berkontribusi sebesar $0,0002 \%$ dari total kapasitas penyerapan karbondioksida dunia.

Daerah Tangkapan Sistem Goa Pindul memiliki peran dalam menekan pemanasan global yang diakibatkan oleh peningkatan karbondioksida di atmosfer. Penyerapan karbondioksida atmosfer oleh DTA Sistem Goa Pindul membantu dalam mengurangi emisi karbondioksida. Besarnya penyerapan karbondioksida oleh DTA Sistem Goa Pindul jauh melebihi emisi karbondioksida yang dihasilkan oleh kendaraan dan industri di Indonesia. Menurut World Bank, emisi karbondioksida di Indonesia sebesar 2,3 ton setiap tahun. Akan tetapi, tidak semua emisi karbondioksida tersebut dapat diserap dalam proses karstifikasi karena tidak semua wilayah terdapat bentangalam karst. Penyerapan karbondioksida oleh DTA Sistem Goa Pindul pun sebatas pada karbondioksida sekitar DTA Sistem Goa Pindul saja.

\section{Kesimpulan}

Kesimpulan dari penelitian ini adalah sebagai berikut:

1. Proses karstifikasi di Daerah Tangkapan Air Sistem Goa Pindul terjadi secara intensif. Hal ini dipengaruhi oleh tutupan vegetasi rapat, curah 
hujan tinggi, dan suhu yang tinggi. Akan tetapi, perilaku manusia seperti pembukaan lahan untuk kawasan wisata dengan cara menebang hutan dan menambang batugamping menyebabkan penurunan intensitas proses karstifikasi;

2. Daerah Tangkapan Air Sistem Goa pindul memiliki potensi besar untuk melakukan penyerapan karbondioksida di atmosfer. Sebesar 966,79 ton/tahun/luas karbondioksida diserap dalam proses karstifikasi untuk melarutkan 8.056,57 ton batugamping; dan

3. Daerah Tangkapan Air Sistem Goa Pindul berperan dalam menekan pemanasan global dengan melakukan penyerapan karbondioksida di atmosfer. Kapasitas penyerapan karbondioksida yang diserap tersebut melebihi emisi karbondioksida yang bertambah 2,3 ton setiap tahunnya di Indonesia.

\section{Pengakuan}

Penelitian ini merupakan bagian dari hibah Penelitian Unggulan

Perguruan Tinggi (PUPT) Kementerian Riset, Teknologi dan Pendidikan Tinggi (Kemenristekdikti) tahun 2016 yang berjudul "Karakterisasi Hidrologi dan Banjir di Sungai Bawah Tanah Goa Pindul untuk Pengelolaan Pariwisata Berkelanjutan Berbasis Manajemen Kebencanaan" dengan nomor kontrak 679/UN1-P.III/LT/DIT-LIT/2016.

\section{Daftar Pustaka}

Adji, T.N. 2013. Kondisi Daerah Tangkapan Sungai Bawah Tanah Karst Gunungsewu dan Kemungkinan Dampak Lingkungannya Terhadap Sumberdaya Air (Hidrologis) Karena Aktivitas Manusia. dalam Sudarmadji; Haryono, E; Adji, T.N.; Widyastuti, M.; Harini, R.; Nurjani, E.; Cahyadi, A. dan Nugraha, H. (eds) 2013. Ekologi Lingkungan Kawasan Karst Indonesia: Menjaga Asa Kelestarian Kawasan Karst Indonesia. Yogyakarta: Penerbit Deepublish.

Blair, Jr. dan Robert, W. 1986. Karst Landforms and Lakes. dalam Short, N.M. dan Blair Jr, Robert W. (eds) 1986. Geomorphology from Space: A Global Overview of Regional Landforms. Washington, D.C.: Government Printing Office.

Cahyadi, A. 2010. Pengelolaan Kawasan Karst dan Peranannya dalam Siklus Karbon di Indonesia. Prosiding Seminar Nasional Perubahan Iklim. Yogyakarta: Sekolah Pascasarjana Universitas Gadjah Mada.

Cahyadi, A.; Prabawa, A. dan Putranto, S.A. 2013a. Pengelolaan Kawasan Karst Gunungsewu Sebagai Upaya Melestarikan Fungsi Penyerapan 
Karbondioksida. dalam Marfai, M.A. dan Widyastuti, M. 2013. Pengelolaan Lingkungan Zamrud Khatulistiwa. Yogyakarta: Pintal.

Cahyadi, A.; Pratiwi. E.S. dan Fatchurohman, H. 2013b. Metode-metode Identifikasi Karakteristik Daerah Tangkapan Air Sungai Bawah Tanah dan Mata Air Kawasan Karst: Suatu Tinjauan. dalam Marfai, M.A. dan Widyastuti, M. 2013. Pengelolaan Lingkungan Zamrud Khatulistiwa. Yogyakarta: Pintal.

Cahyadi, A. 2014. Keunikan Hidrologi Kawasan Karst: Suatu Tinjauan. dalam Cahyadi, A.; Prabawa, B.A.; Tivianton, T.A. dan Nugraha, H. 2014. Ekologi Lingkungan Kawasan Karst Indonesia: Mejaga Asa Kelestarian Kawasan Karst Indonesia, Edisi 2. Yogyakarta: Deepublish.

Cahyadi, A. dan Priadmodjo, A. 2015. Pengaruh Penambangan Gamping terhadap Fungsi Penyerapan Karbondioksida $\left(\mathrm{CO}_{2}\right)$ Atmosfer di Kawasan Karst Kecamatan Ponjong, Kabupaten Gunungkidul. Prosiding Seminar Nasional Geospasial Day. Surakarta: Universitas Sebelas Maret.

Daoxian, Y. 2002. The Carbon Cycle in Karst, IGCP Report. Guilin: Institute of Karst Geology.

Darajati, W.; Pratiwi, S.; Herwinda, E.; Radiansyah, A.D.; Nalang, V.S.; Nooryanto, B.; Rahajoe, J.S.; Ubaidillah, R.; Maryanto, I.; Kurniawan, R.; Prasetyo, T.A.; Rahim, A.; Jefferson, J. dan Hakim, F. 2016. Indonesian Biodiversity Strategy and Action Plan (IBSAP) 2015-2020. Jakarta: Kementerian Perencanaan Pembangunan Nasional/BAPPENAS.

Ford, D. and Williams P.D. 2007. Karst Hydrogeology and Geomorphology. Chicester: John Wiley and Sons.

Hadisusanto, N. 2010. Aplikasi Hidrologi. Yogyakarta: Penerbit Kanisius.

Haryono, E. dan Adji, T.N. 2004. Pengantar Geomorfologi dan Hidrologi

Karst. Yogyakarta: Kelompok Studi Karst Fakultas Geografi Universutas Gadjah Mada.

Haryono, E. 2011. Atmospheric Carbon Dioxide Sequestration Trough Karst Denudation Processes. Proceeding Asian trans-disciplinary Karst Converence. Yogyakarta: Universitas Gadjah Mada.

Murdiyarso, D. 2005. Sepuluh Tahun Perjalanan Negoisasi Konvensi Perubahan Iklim. Edisi Kedua. Jakarta: Penerbit Buku Kompas.

Sosrodarsono, S. dan Takeda, K. 2006. Hidrologi untuk Pengairan, Edisi Keenam. Jakarta: PT Pradnya Paramita.

Suprianto, T. dan Solihat, A. 2012. Siklus Karbon dan Hutan. Jakarta: UNREDD Programme Indonesia. 
Triatmodjo, B. 2010. Hidrologi Terapan. Yogyakarta: Beta Offset.

Zhongcheng, J. and Daoxian, Y. 1999. $\mathrm{CO}_{2}$ Source-Sink in Karst Processes in Karst Areas of China. Episodes, 22(1): 33 -35.

Makalah ini merupakan bagian dari Buku Seri Bunga Rampai dengan Judul "Hidrologi dan Kepariwisataan Kawasan karst Goa Pindul Kabupaten Gunungkidul" dengan Editor Slamet Suprayogi, Setyawan Purnama, Ahmad Cahyadi, Hendy Fatchurohman. Buku ini diterbitkan oleh Badan Penerbit Fakultas Geografi (BPFG) Universitas Gadjah Mada di Yogyakarta Tahun 2016. Makalah ini termuat dalam Halaman 68-82. 